\title{
Fuels Reduction in a Western Coniferous Forest: Effects on Quantity and Quality of Forage for Elk
}

\author{
Ryan A. Long, ${ }^{1}$ Janet L. Rachlow, ${ }^{2}$ John G. Kie, ${ }^{3}$ and Martin Vavra ${ }^{4}$ \\ Authors are ${ }^{1}$ Graduate Student, Department of Biological Sciences, Idaho State University, Pocatello, ID 83209, USA; ${ }^{2}$ Associate Professor, Department \\ of Fish and Wildlife Resources, University of Idaho, Moscow, ID 83844, USA; ${ }^{3}$ Research Professor, Department of Biological Sciences, Idaho State \\ University, Pocatello, ID 83209, USA; and ${ }^{4}$ Disturbance Ecology and Management Team Leader, USDA Forest Service, Pacific Northwest Research \\ Station, La Grande, OR 97850, USA.
}

\begin{abstract}
Use of mechanical thinning and prescribed fire to reduce fuels in dry forest ecosystems has become increasingly common in western North America. Nevertheless, few studies have quantified effects of fuels reduction treatments on wildlife. We evaluated effects of fuels reduction on quantity and quality of forage available to elk (Cervus elaphus) in northeastern Oregon. From 2001 to 2003, 26 stands of true fir (Abies spp.) and Douglas-fir (Pseudotsuga menziesii [Mirbel] Franco) were thinned and burned, whereas 27 similar stands were left untreated to serve as experimental controls. We estimated percentage of cover, percentage of in vitro dry-matter digestibility (digestibility), and percentage of nitrogen $(\% \mathrm{~N})$ of 16 important forage species and genera in treatment and control stands during spring (May-June) and summer (July-August) of 2005 and 2006. Quantity and quality of forage were lower in summer than spring in both stand types. In contrast, total cover of forage was higher in treatment than in control stands during spring, whereas the opposite was true during summer. For graminoids, \% $\mathrm{N}$ was higher in control than in treatment stands whereas digestibility did not differ between stand types. For forbs, neither index of forage quality differed between stand types. When treatment stands were separated by years since burning, $\% \mathrm{~N}$ and digestibility of forbs and \% $\mathrm{N}$ of graminoids increased from 2 to $5 \mathrm{yr}$ following treatment, and by the fifth year after burning had exceeded maximum values observed in control stands in both seasons. As a result of the interacting effects of fuels reduction and season on forage characteristics, treated stands provided better foraging opportunities for elk during spring, whereas control stands provided better foraging opportunities during summer. Consequently, maintaining a mosaic of burned and unburned (late successional) habitat may be of greater benefit to elk than burning a large proportion of a landscape.
\end{abstract}

\section{Resumen}

El uso del raleo mecánico y los fuegos prescritos para reducir combustibles en ecosistemas de bosques secos ha comenzado ser común cada vez más en el oeste de America del Norte. Sin embargo, pocos estudios han cuantificado los efectos de los tratamientos de reducción de combustible en la vida silvestre. Nosotros evaluamos los efectos de la reducción de combustible sobre la cantidad y calidad del forraje para el alce (Cervus elaphus) en el noreste de Oregón. Desde el 2001 al 2003, 26 rodales de pino verdadero (Abies spp.) y pino de Oregón (Psendotsuga menziesii [Mirbel] Franco) fueron reducidos y quemados, mientras que 27 rodales similares fueron dejados sin tratar como controles experimentales. Nosotros estimamos el porcentaje de cobertura, el porcentaje in vitro de digestibilidad de materia seca y el porcentaje de nitrógeno $(\% \mathrm{~N})$ de 16 especie y géneros de forrajes importantes de los rodales en el tratamiento y el control durante la primavera (Mayo y Junio) y el verano (Julio y Agosto) del 2005 y 2006. La cantidad y calidad del forraje fueron más bajas en el verano que en primavera en ambos tipos de rodales. Por el contrario, el total de cobertura de forraje fue más alto en los rodales de tratamiento que en el control durante la primavera, mientras que lo opuesto fue observado durante el verano. Para las gramíneas, el \% de N fue más alto en los rodales de control que en el tratamiento, mientras que la digestibilidad no cambio entre los tipos de rodales. Para las herbáceas, ninguno de los índices de calidad de forraje cambio entre los tipos de rodales. Cuando los rodales de tratamiento fueron separados por años, no obstante, el \% de $\mathrm{N}$ y la digestibilidad de las herbáceas y el \% de $\mathrm{N}$ de las gramíneas aumentaron desde los 2 a los 5 años seguido del tratamiento, y para el quinto año después de la quema excedieron los valores máximos observados en los rodales de control en ambas estaciones. Como resultado del efecto de las interacciones de la reducción de fuego y características de la estacionalidad del forraje, los rodales tratados brindaron mejores oportunidades de forrajeo durante el verano. Por consiguiente, mantener un mosaico de hábitats quemados y no quemados (sucesión tardía) podría ser de mayor beneficio para el alce más que quemar una porción grande del paisaje.

Key Words: Cervus elaphus, in vitro dry-matter digestibility, nitrogen, nutrition, Oregon, percentage of cover, prescribed fire

Research was funded by the Joint Fire Science Program, the Rocky Mountain Elk Foundation, and the USDA Forest Service Pacific Northwest Research Station.

At the time of the research, Long was graduate research assistant, Dept of Fish and Wildlife Resources, University of Idaho, Moscow, ID, USA.

Correspondence: Ryan A. Long, Dept of Biological Sciences, Idaho State University, Pocatello, ID 83209, USA. Email: longryan@isu.edu

Manuscript received 13 May 2007; manuscript accepted 21 December 2007.

\section{INTRODUCTION}

Over the past century, fire exclusion has altered natural fire regimes across much of western North America, and as a result ecological relationships and processes occurring in many forest ecosystems have been modified (Dodge 1972; Belsky and Blumenthal 1997; McCullough et al. 1998; Mast et al. 1999). 
Ecological consequences of fire exclusion have included increased likelihood of large, severe fires (Dodge 1972; Pyne 1997); denser, more spatially uniform forests (Parsons and DeBenedetti 1979; Ottmar and Sandberg 2001); increased vulnerability of stands to disease and insect outbreaks (McCullough et al. 1998; Tiedemann et al. 2000; Hayes and Daterman 2001); substantial alteration of species composition and structure (Dodge 1972; Jourdonnais and Bedunah 1990); and a reduction in high-quality wildlife habitat (Peck and Peek 1991; Craighead et al. 1995). Consideration of these effects has led to increased use of mechanical thinning and prescribed fire to reduce fuels in fire-adapted ecosystems (Dodge 1972; Belsky and Blumenthal 1997; Covington et al. 1997; Tiedemann et al. 2000). Nevertheless, relatively few studies have examined effects of fuels reduction treatments on wildlife, particularly in an experimental framework, and although fuels reduction often is assumed to benefit wildlife, existing literature documents both positive and negative effects for a variety of species (Jourdonnais and Bedunah 1990; Peck and Peek 1991; Connelly et al. 2000; Maehr and Larkin 2004).

Application of mechanical thinning or prescribed fire can affect wildlife in a variety of ways (McMahon and deCalesta 1990). Perhaps the most important of these, however, is through alteration of quality, availability, or distribution of forage resources (Parker and Morton 1978; Carlson et al. 1993; Masters et al. 1993; Perryman et al. 2002). Nutritional quality and rates of primary production of herbaceous forage species often have been reported to increase following fire (Carlson et al. 1993; Grogan et al. 2000; Perryman et al. 2002; Van Dyke and Darragh 2007). The two primary mechanisms for this response are increased availability of light and water resulting from a reduction in tree canopy cover (Metlen et al. 2004) and increased availability of nutrients (primarily nitrogen) in the soil (Grogan et al. 2000; Carter and Foster 2004; but see Klemmedson 1976). Mechanical thinning may produce similar results, although response of understory vegetation to thinning often is slower than response to burning (Metlen et al. 2004). Published effects of fire on woody browse have been less consistent. For example, some authors have reported decreased abundance of shrubs after burning (Busse et al. 2000; Weekley and Menges 2003; Metlen et al. 2004; Metlen and Fiedler 2006), whereas others have reported either very little effect of fire (Quinlan et al. 2003) or increased abundance of shrubs following fire (Carlson et al. 1993; Pendergrass et al. 1998; Ayers et al. 1999). Such variability among studies likely results from species-specific differences in ability of shrubs to resprout following fire.

Although differential responses of vegetation to similar types of disturbance result from a variety of factors, site-specific differences in historical disturbance regime and initial species composition likely contribute to much of the variability. Plants exhibit a wide range of unique adaptations to disturbance (Agee 1993). As a result of this diversity, as well as differences in life-history characteristics such as growth phenology and reproductive strategy (Metlen et al. 2004), vegetative communities with different species assemblages and disturbance histories are not likely to respond to fuels reduction in the same way. Consequently, effects of fuels reduction treatments on quantity and quality of forage for wildlife may differ markedly across space and time. This highlights the need to evaluate effects of fuels reduction at multiple sites, ideally in an experimental framework with spatial and temporal replication of treatments (Hurlbert 1984).

We studied effects of an experimental fuels reduction program conducted over a relatively large geographic area $\left(78 \mathrm{~km}^{2}\right)$ on quantity (percentage of cover) and nutritional quality (percentage of nitrogen $[\% \mathrm{~N}]$ and digestibility) of forage available to elk (Cervus elaphus) at the Starkey Experimental Forest and Range (hereafter Starkey) in northeastern Oregon. Fifty-three stands of true fir (Abies spp.) and Douglas-fir (Pseudotsuga menziesii [Mirbel] Franco) at Starkey suffered high rates of mortality from a spruce budworm (Choristoneura occidentalis) outbreak in the 1980s, which eventually resulted in high loads of dead and standing woody fuels. Half of those stands were subjected to fuels reduction treatments (mechanical thinning followed by prescribed fire) over a 3-yr period (2001-2003) and half were left untreated to serve as experimental controls. We estimated percentage of cover and nutritional quality of several key forage species in each stand during spring and summer of 2005 and 2006 (2$5 \mathrm{yr}$ after treatment). In addition we characterized stands with respect to overstory conditions and abiotic ground cover (dead and downed material, rocks, and bare ground). We used those data to test the following hypotheses. First, because we anticipate increased availability of light and water following fuels reduction, we hypothesize that percentage of cover of live (green) forage species will be higher on average in treatment than in control stands. Second, because prescribed fire likely will increase availability of soil nutrients (particularly nitrogen), we hypothesize that nutritional quality of forage species will be higher in treatment than in control stands. Third, quantity (percentage of cover) of forage species will increase from 2 to $5 \mathrm{yr}$ after treatment, but quality will either remain stable or slowly decline as nutrients again become limited. Finally, differences between treatment and control stands will be most evident in spring, as a combination of high temperatures and lack of precipitation during summer will cause plants in both treatment and control stands to rapidly senesce. We tested these hypotheses in an experimental framework to evaluate ecological consequences of two commonly applied forest management techniques.

\section{METHODS}

\section{Study Area}

Starkey is a $101-\mathrm{km}^{2}$ research area located in the Blue Mountains of northeastern Oregon (lat $45^{\circ} 13^{\prime} \mathrm{N}$, long $\left.118^{\circ} 31^{\prime} \mathrm{W}\right)$ and managed by the US Forest Service (USFS). The site is enclosed by a $2.4-\mathrm{m}$ high fence, which also divides Starkey into several distinct research areas (Bryant et al. 1993; Rowland et al. 1997). We conducted research in Main Study Area, which is the largest at Starkey at $78 \mathrm{~km}^{2}$. Elevations at Starkey range from 1120 to $1500 \mathrm{~m}$, and the site supports a mosaic of coniferous forests, shrublands, and grasslands, with moderately sloping uplands dissected by numerous drainages (Stewart et al. 2002). Common plant communities include bunchgrasses (Festuca idahoensis Elmer, Poa secunda J. Presl, and Pseudoroegneria spicata [Pursh] A. Löve), ponderosa pine (Pinus ponderosa P. \& C. Lawson), Douglas-fir, grand fir 
(Abies grandis [Dougl. ex D. Don] Lindl.), and lodgepole pine (Pinus contorta Dougl. ex Loud.). Botanical nomenclature throughout our paper follows that of the US Department of Agriculture Natural Resources Conservation Service (2007). Cattle (about 500 cow-calf pairs) were introduced to Main Study Area each year around 15 June and were moved in a deferred-rotation system among three pastures separated by barbed-wire fence and an additional pasture outside the study area. Detailed descriptions of Starkey are provided by Skovlin (1991), Wisdom et al. (1993), and Rowland et al. (1997, 1998).

A spruce budworm outbreak in the late 1980s caused extensive mortality of true fir and Douglas-fir in densely stocked stands throughout Starkey, which in turn resulted in high loads of dead and standing fuels $\left(>150\right.$ tons $\cdot \mathrm{ha}^{-1}$ in many stands). A concomitant increase in the likelihood of large, severe fires led the USFS to initiate an experimental fuels reduction program at Starkey in 2001, with the objective of reducing fuel loadings to $35-50$ tons $\cdot \mathrm{ha}^{-1}$ in treated stands. A total of 53 stands that experienced high rates of tree mortality from the spruce budworm outbreak were identified. Twenty-six of those stands were selected for treatment (mechanical thinning followed by prescribed fire) and 27 were left untreated to serve as experimental controls. As a result of logistical constraints imposed by topography and size of some stands, it was not possible to assign treatments in a completely random fashion. Every effort was made, however, to randomly assign treatments to the greatest extent possible within those constraints, and although control stands were, on average, larger than treatment stands (mean treatment stand area $=26 \mathrm{ha}$, range $=2-214 \mathrm{ha}$; mean control stand area $=55$ ha, range $=4-168 \mathrm{ha}$ ), ranges of average slope, aspect, and elevation were comparable between stand types. Plant associations and soil characteristics also were relatively similar among stands prior to treatment. Mean soil depth (A and B horizons) was $29.8 \mathrm{~cm}$ in treatment stands (range $=20.8$ $49.5 \mathrm{~cm}$ ) and $30.8 \mathrm{~cm}$ in control stands (range $=19.2$ $45.8 \mathrm{~cm}$ ). Vegetation associations in all stands were at or near climax stage prior to treatment, and were dominated either by Douglas-fir (seven treatment stands and nine control stands) or grand fir (19 treatment stands and 18 control stands). Fuels reduction treatments took place from 2001 to 2003. During that time each treated stand was mechanically thinned between May and October and was then treated with prescribed fire in September or October of either the same year or the following year. Time between thinning and burning treatments ranged from 1 to $13 \mathrm{mo}$, which resulted in different levels of plant regeneration among treatment stands prior to burning. Nearly all such regeneration was removed, however, following application of prescribed fire treatments, and thus we consider only two stand types in our analyses: control stands and treatment (burned) stands. All treatment stands were broadcast-burned, with limited pile-burning in some stands. Mean flame height was $0.81 \mathrm{~m}$ (range $=0.46-1.22 \mathrm{~m}$ ) and mean rate of spread was $0.07 \mathrm{~km} \cdot \mathrm{h}^{-1}\left(\right.$ range $\left.=0.02-0.20 \mathrm{~km} \cdot \mathrm{h}^{-1}\right)$. Ten stands initially were treated in 2001 (six thinned, four thinned and burned), 11 in 2002 (seven thinned, four thinned and burned), and five in 2003 (all thinned and burned; Fig. 1). We digitized boundaries of all stands in a geographic information system (ArcGIS 9.0) from a combination of 28.5$\mathrm{m}$ resolution LANDSAT Thematic Mapper imagery obtained

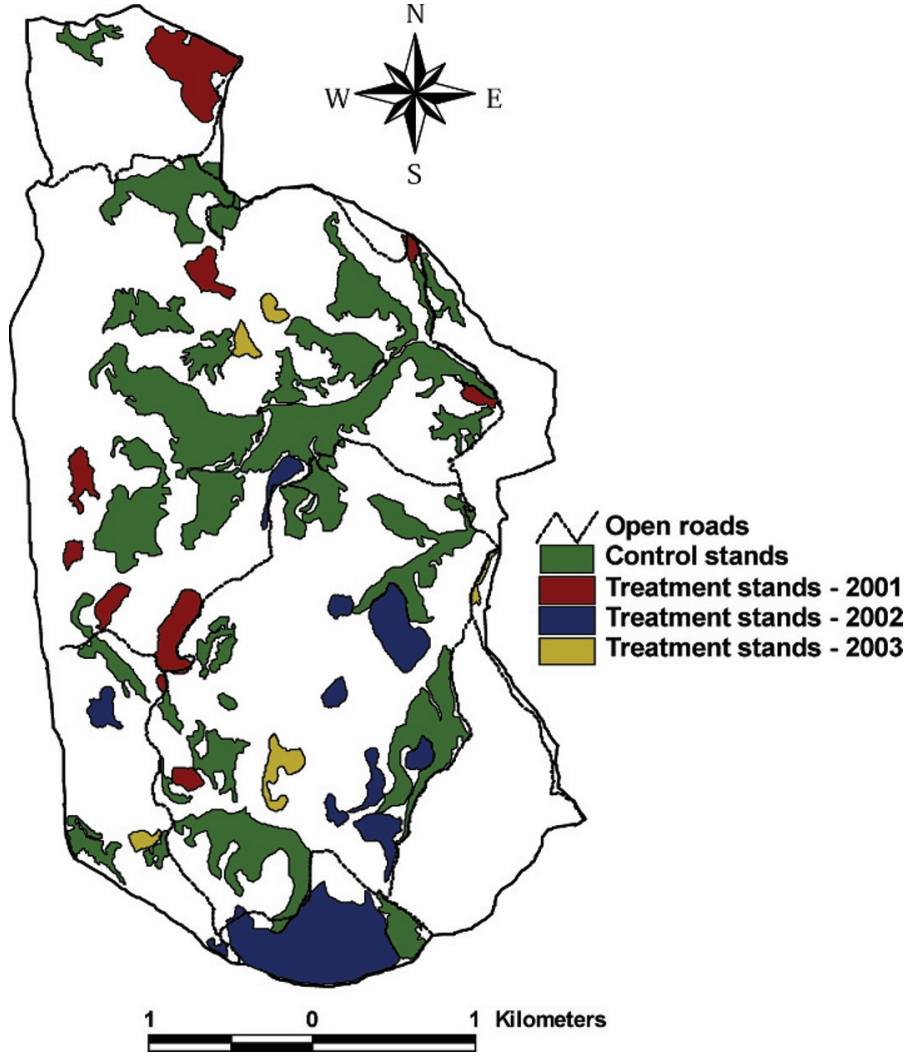

Figure 1. Locations of 26 forest stands treated with mechanical thinning and prescribed fire from 2001 to 2003 and 27 untreated control stands at the Starkey Experimental Forest and Range, Oregon. Years associated with treatment stands indicate year of initial treatment (either thinning or thinning and burning).

from the US Geological Survey for summers of 2000, 2003, and 2004 , and a 1-m resolution digital orthophoto of Starkey from summer of 2002.

\section{Sampling Design}

Sampling was conducted from May through August 2005 and 2006. We sampled live (green) understory vegetation and abiotic ground cover in $1-\mathrm{m}^{2}$ quadrats nested within $4 \times 10 \mathrm{~m}$ plots centered lengthwise along $100-\mathrm{m}$ line transects. Plots were located at $10-\mathrm{m}$ intervals along each transect and two quadrats were placed in opposite corners of each plot so that five plots containing two quadrats each were associated with each transect. Start locations and bearings for transects in each stand were assigned at random in a geographic information system subject to the following constraints: transects were a minimum of $50 \mathrm{~m}$ apart at all points, start locations were a minimum of $100 \mathrm{~m}$ apart, and each transect was fully contained within the boundary of the stand. The number of transects sampled in each stand was proportional to the area of the stand and ranged from 4 to 24 . We sampled a total of 408 transects during our study. We stratified our sampling by season such that half of the transects in each stand were sampled in spring (May and June) and half were sampled in summer (July and August) each year. During the first sampling period (spring 2005) we determined the order in which to sample the 53 stands by first randomizing the order in which 
control stands were sampled. After sampling a control stand, we then sampled the closest treatment stand in an effort to minimize effects of stand location on our results. Despite this approach, however, distances between each control stand and the nearest treatment stand ranged from $<100 \mathrm{~m}$ to $5500 \mathrm{~m}$, and thus our design cannot be considered paired (K. Steinhorst, personal communication, December 2006). All stands were sampled in the same order during each subsequent sampling period (summer 2005 and spring and summer 2006), and no part of any transect was sampled more than once for the duration of our study. Delineation of seasons was based on past patterns of temperature and precipitation at Starkey, and reflected seasonal changes in plant phenology (Stewart et al. 2002, 2006).

We used handheld global positioning system units to navigate to the start location of each transect, and compasses adjusted for declination to position transects on the ground based on preassigned bearings. Actual stand boundaries were not always as discrete as digitized boundaries and, consequently, transects occasionally appeared to run into edge habitat bordering the stands. When this occurred, we retained the transect and sampled all associated quadrats if $>50 \%$ of its length appeared to be located inside the stand, and used an alternate transect if $>50 \%$ of its length appeared to be outside the stand. Start locations and bearings for alternate transects were assigned in the same manner and were subject to the same constraints as primary transects. Of 408 transects sampled in our study, $<10 \%$ were alternates, and we estimate that $<2 \%$ of sampled quadrats were located in edge habitat.

\section{Percentage of Cover}

We focused our collection of cover data on species and genera presumed to be important to female elk at Starkey based on previous microhistological analysis of fecal samples (Stewart et al. 2003). Fresh $(<2$ d old) fecal samples were obtained from elk on the study site by Stewart et al. (2003) while sampling vegetation during July and August of 1997, and were analyzed for diet composition at the Wildlife Habitat Nutrition Laboratory at Washington State University. We sampled a total of 16 species or genera comprising roughly $60 \%$ of undigested dry matter in the feces. Graminoids sampled were wheatgrass (Pseudoroegneria spp.), smooth brome (Bromus inermis Leyss.), mountain brome (Bromus marginatus Nees ex Steud.), pinegrass (Calamagrostis rubescens Buckl.), Geyer's sedge (Carex geyeri Boott), Ross' sedge (Carex rossii Boott), orchardgrass (Dactylis glomerata L.), oatgrass (Danthonia spp.), fescue (Festuca spp.), and bluegrass (Poa spp.). Sampled forbs were western yarrow (Achillea millefolium L. var. occidentalis DC.), arnica (Arnica spp.), milkvetch (Astragalus spp.), Indian paintbrush (Castilleja spp.), and lupine (Lupinus spp.). The only shrub that constituted $\geq 1 \%$ of undigested dry matter in the feces (Stewart et al. 2003) was creeping barberry (Mahonia repens [Lindl.] G. Don), and thus creeping barberry was the only woody species we sampled. Most of these species and genera also are known to constitute an important component of elk diets in other areas of northeastern Oregon (Miller et al. 1981). In each sampling quadrat, we made ocular estimates of percentage of cover (Bonham 1989) for each of the 16 species or genera, as well as for total vegetation and vegetation categories (graminoids, forbs, and shrubs). To minimize effects of observer bias (Mitchell et al. 1988), we recorded cover data categorically based on a standard cover class scale (McCune and Grace 2002). Classes 0 through 8 included the following percentages, respectively: $0 \%, 0 \%-1 \%$, $1 \%-5 \%, 5 \%-25 \%, 25 \%-50 \%, 50 \%-75 \%, 75 \%-95 \%, 95 \%-$ $99 \%$, and $99 \%-100 \%$ (McCune and Grace 2002). We also recorded cover class estimates for five categories of abiotic ground cover: litter and fine fuels (twigs, bark, leaves, needles, branches, or other organic matter lying above the mineral soil), coarse woody debris (downed woody material $>10 \mathrm{~cm}$ in diameter and $>1 \mathrm{~m}$ in length), snags and stumps, rock, and bare ground. Cover data were recorded using an Allegro CX field computer (Juniper Systems Inc., Logan, UT).

\section{Forage Quality}

In order to maximize the number of quadrats that could be clipped for nutritional analysis in each stand and season, we truncated our species list and clipped the top 10 species or genera (based on percentage of undigested dry matter in the feces; Stewart et al. 2003). Species or genera that we included in cover estimation but did not clip were wheatgrass, smooth brome, mountain brome, arnica, milkvetch, and Indian paintbrush. Plants were clipped in four quadrats per stand during each of the four sampling periods in our study. To encompass spatial variation among plants, we separated clipped quadrats within stands to the greatest extent possible based on the number of transects in each stand. For example, when only one transect was sampled, we clipped the first, fourth, seventh, and tenth quadrats, and when four transects were sampled we clipped the first quadrat on each transect. In each quadrat we clipped portions of plants typically eaten by elk, including the inflorescence and basal leaves in forbs and graminoids and current annual growth in shrubs (Beck and Peek 2005). In addition we removed all dead material from our samples. Within each sampling period, samples from clipped quadrats within a stand were combined into functional groups (graminoids, forbs, and shrubs) in proportion to their occurrence in the clipped quadrats and dried in a forced-air oven for $24 \mathrm{~h}$ at $40^{\circ} \mathrm{C}$ within $8 \mathrm{~h}$ of collection. We ground dried samples to $1 \mathrm{~mm}$ and stored them in plastic bags at room temperature prior to laboratory analysis. We collected a total of 237 forage samples in spring (104, 97, and 36 for graminoids, forbs, and shrubs, respectively) and 230 samples in summer $(106,90$, and 34 for graminoids, forbs, and shrubs, respectively). Sample sizes for nutritional analysis were approximately equal across stand types in both seasons ( $n=121$ for control stands and $n=116$ for treatment stands in spring; $n=117$ for control stands and $n=113$ for treatment stands in summer). Ground plant samples were analyzed for in vitro dry-matter digestibility (digestibility) and $\% \mathrm{~N}$ at the University of Alaska, Fairbanks. Rumen inoculum was obtained from fistulated reindeer (Rangifer tarandus) housed at the Institute of Arctic Biology's Large Animal Research Station. Reindeer were not preinoculated with forage from the study area, but, similar to elk at Starkey, reindeer diets during spring and summer included a large proportion of forbs and graminoids. Regardless, our results should be interpreted as relative rather than absolute differences in forage quality 
between treatment and control stands. Apparent digestibility was estimated using techniques described by Tilley and Terry (1963), and \% N was determined by Kjeldahl's analysis.

\section{Characterization of Overstory Conditions}

We characterized overstory conditions in each treatment and control stand by estimating tree densities for individual species and size classes. For each transect we identified all trees in the five $40-\mathrm{m}^{2}$ plots to species and recorded either height (trees $\leq 135 \mathrm{~cm}$ tall) or diameter at breast height $(\mathrm{DBH}$; trees $>135 \mathrm{~cm}$ tall). We then estimated species-specific tree densities for three size classes (trees $\leq 135 \mathrm{~cm}$ tall, trees $>135 \mathrm{~cm}$ tall but $<23 \mathrm{~cm} \mathrm{DBH}$, and trees $\geq 23 \mathrm{~cm} \mathrm{DBH}$ ) in each stand by dividing the total number of trees measured by the total area sampled during our study. All tree species sampled during our study were conifers, and thus we pooled tree data across years and seasons based on the assumption that there was minimal transition of trees from one size class to another during the $2 \mathrm{yr}$ of our study. We report all density estimates as means \pm standard errors (SE).

\section{Statistical Analyses}

We converted cover class data to their class-specific median values for analysis of cover as a continuous variable (Bonham 1989). We then averaged median cover values across quadrats within a transect and transects within a stand to produce an estimate for each forage species or genus, total vegetation, graminoids, forbs, and shrubs for each stand and sampling period. Median values of abiotic cover also were averaged across seasons. We arcsine-square root transformed percentage of cover estimates prior to statistical analysis to meet assumptions of normality (Neter et al. 1996). In fall 2005, a small wildfire completely burned one control stand. Consequently, data for that stand were obtained during 2005 only, and total sample sizes for analyses of biotic and abiotic cover data were 210 and 105 , respectively.

We evaluated effects of stand type, season, and year on percentage of cover of forage species, and stand type and year on abiotic ground cover using multivariate analysis of variance (MANOVA). The design in each case was a double split plot (in time and space for analyses of forage cover) or split plot (in space only for analyses of abiotic cover) approach to a randomized complete block with repeated measures. In each case the stand was the sampling unit, and we blocked by stand identification nested within stand type in both analyses to control for effects of interstand variability. We sampled each stand once per season in 2005 and again in 2006, and thus both the season and year effects were repeated measures in analyses of forage cover. Likewise, because all stands were sampled once in spring and once in summer during both years, season represented the first (temporal) split plot. Stand type (treatment or control) represented the second (spatial) split plot. Interactions among treatment effects also were included in each analysis. Prior to interpretation of results, we evaluated residual plots for dependent variables to assess adherence to assumptions of MANOVA. In both cases this evaluation indicated marginal normality of all transformed dependent variables. Following multivariate significance of a main effect, we used canonical correlation analysis to determine which dependent variables were responsible for overall significance of that effect (Johnson and Wichern 2002). For dependent variables identified in the canonical analysis, we conducted analyses of variance (ANOVAs) that included all main effects that were significant in the MANOVA and, where appropriate, significant interaction terms. We report means and standard errors for those variables by stand type and season for vegetative cover and stand type and year for abiotic ground cover. We set statistical significance at $\alpha \leq 0.05$. All statistical analyses were performed using SAS software (PROC GLM; SAS Institute 2002).

We conducted an additional MANOVA using vegetative cover data from treatment stands only. Season and years since burning $(2,3,4$, or 5$)$ were included as treatment effects and we blocked by stand nested within years since burning. Total sample size was 104 , and we generally proceeded with this analysis in the manner described previously for cover data. In addition, we followed univariate ANOVAs with multiple comparison procedures using Tukey's honestly significant difference test for years since burning. It was not possible, however, to perform within-season ANOVAs blocked by unit nested within years since burning for purposes of multiple comparisons as a result of insufficient error degrees of freedom. Consequently we only conducted multiple comparisons for years since burning when ANOVA results indicated a nonsignificant season affect.

We also used a series of MANOVAs to evaluate effects of stand type, season, year, and years since burning on digestibility and $\% \mathrm{~N}$ of forage. We were unable to obtain a forage sample for each functional group in all stands, seasons, and years. Consequently, sample sizes differed among the three functional groups, so we chose to analyze each group independently. Sample sizes were 207, 185, and 67 for graminoids, forbs, and shrubs, respectively. In addition, we did not analyze effects of season and years since burning on quality of shrubs because it was not possible to block that analysis by unit nested within years since burning as a result of insufficient replication.

\section{RESULTS}

\section{Forage Abundance}

The effects of fuels reduction treatments on forage abundance at Starkey varied among species. Percentage of cover of nearly all species, however, was higher in spring than summer, and for many species cover was higher in 2006 than 2005. Although the season $\times$ year interaction term was significant in the MANOVA for vegetative cover $(P=0.02)$, that significance resulted from a difference in magnitude between seasons among years rather than direction of the seasonal effect between years. Consequently, we chose to move forward with interpretation of main effects in that analysis, all three of which were statistically significant (Wilk's $\Lambda=0.27, F_{20,136}=18.27$, $P<0.0001$ for stand type; Wilk's $\Lambda=0.47, F_{20},{ }_{136}=7.78$, $P<0.0001$ for season; Wilk's $\Lambda=0.61, F_{20}, 1_{136}=4.17$, $P<0.0001$ for year). Canonical correlation analysis indicated that 11 of 20 vegetative dependent variables contributed to the overall significance of the stand type effect, six variables contributed to the season effect, and four variables contributed 
Table 1. Percentage of cover (mean \pm SE) of nine species or genera and three general classes of vegetation in burned (treatment; $n=26$ ) and unburned (control; $n=27$ ) forest stands during spring (May-June) and summer (July-August) at the Starkey Experimental Forest and Range (Starkey), Oregon. Estimates are averaged over 2005 and 2006. Diet composition for elk at Starkey was estimated from previous microhistological analysis of fecal samples (Stewart et al. 2003).

\begin{tabular}{|c|c|c|c|c|c|c|c|}
\hline \multirow[b]{2}{*}{ Plant species } & \multirow{2}{*}{$\begin{array}{l}\% \text { of } \\
\text { diet }\end{array}$} & \multicolumn{2}{|c|}{ Treatment stands } & \multicolumn{2}{|c|}{ Control stands } & \multicolumn{2}{|c|}{$P$ value $^{1}$} \\
\hline & & Spring & Summer & Spring & Summer & Stand type & Season \\
\hline \multicolumn{8}{|l|}{ Graminoids } \\
\hline Poa spp. & 6.05 & $0.54 \pm 0.07$ & $0.34 \pm 0.06$ & $0.37 \pm 0.09$ & $0.21 \pm 0.04$ & 0.0046 & 0.0011 \\
\hline Danthonia spp. & 1.96 & $0.13 \pm 0.04$ & $0.09 \pm 0.03$ & $0.03 \pm 0.01$ & $0.02 \pm 0.01$ & $<0.0001$ & 0.5789 \\
\hline Dactylis glomerata L. & 4.10 & $3 e-3 \pm 3 e-3$ & $4 e-3 \pm 3 e-3$ & $0.02 \pm 0.01$ & $0.02 \pm 0.01$ & 0.0026 & 0.8202 \\
\hline Carex rossii Boott & 3.79 & $0.27 \pm 0.10$ & $0.21 \pm 0.04$ & $0.02 \pm 4 \mathrm{e}-3$ & $0.01 \pm 0.01$ & $<0.0001$ & 0.4816 \\
\hline Calamagrostis rubescens Buckl. & 3.79 & $0.69 \pm 0.15$ & $0.83 \pm 0.13$ & $0.85 \pm 0.10$ & $1.52 \pm 0.19$ & $<0.0001$ & 0.0009 \\
\hline Bromus inermis Leyss. & 1.01 & $0.04 \pm 0.01$ & $0.02 \pm 0.01$ & $0.10 \pm 0.04$ & $0.02 \pm 0.01$ & 0.0270 & 0.0013 \\
\hline \multicolumn{8}{|l|}{ Forbs } \\
\hline Arnica spp. & 1.32 & $3.04 \pm 0.43$ & $1.03 \pm 0.28$ & $4.59 \pm 0.58$ & $1.89 \pm 0.40$ & 0.0002 & $<0.0001$ \\
\hline Achillea millefolium $\mathrm{L}$. & 11.39 & $0.94 \pm 0.11$ & $0.98 \pm 0.16$ & $0.39 \pm 0.04$ & $0.35 \pm 0.05$ & $<0.0001$ & 0.4580 \\
\hline \multicolumn{8}{|l|}{ Shrubs } \\
\hline Mahonia repens (Lindl.) G. Don & 2.07 & $0.23 \pm 0.06$ & $0.31 \pm 0.09$ & $0.59 \pm 0.14$ & $0.72 \pm 0.14$ & $<0.0001$ & 0.4625 \\
\hline Total vegetation & 100.00 & $28.37 \pm 1.31$ & $21.55 \pm 1.46$ & $39.77 \pm 1.65$ & $35.02 \pm 2.11$ & $<0.0001$ & $<0.0001$ \\
\hline Total forbs & 44.73 & $14.51 \pm 0.75$ & $10.30 \pm 0.90$ & $16.21 \pm 0.87$ & $11.84 \pm 1.04$ & 0.1022 & $<0.0001$ \\
\hline Total shrubs & 6.88 & $4.76 \pm 0.57$ & $4.94 \pm 0.43$ & $14.56 \pm 1.28$ & $14.78 \pm 1.72$ & $<0.0001$ & 0.8086 \\
\hline
\end{tabular}

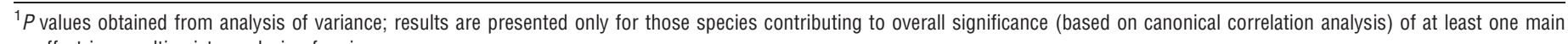
effect in a multivariate analysis of variance.

to the year effect. Only total forb cover contributed to the effect of season but not stand type. We plotted mean values of the four variables responsible for the year effect by stand type, season, and year to determine whether it was reasonable to average cover estimates for those variables across years. Although cover of each variable generally was higher in 2006 than 2005, differences between seasons and stand types were consistent in magnitude and direction across years. Therefore, we report mean cover values averaged across years by stand type and season for all 12 vegetative variables that differed between stand types, seasons, or both $(P \leq 0.05$ based on ANOVA; Table 1).

Of nine forage species or genera that differed significantly in cover between stand types, four (bluegrass, oatgrass, Ross' sedge, and western yarrow) were more abundant in treated stands whereas five (orchardgrass, pinegrass, smooth brome, arnica, and creeping barberry) were more abundant in control stands (Table 1). During both spring and summer, arnica comprised the largest proportion of combined cover of all nine of those species or genera $(\geq 51 \%$ in spring and $27 \%$ in summer; Table 1), and was more abundant in control than treatment stands. Arnica, however, also was the only species or genus for which estimated use by elk (percentage of undigested dry matter in the feces) was ever less than availability (percentage of cover; Table 1), potentially indicating avoidance of arnica by elk at this high abundance. Although combined cover of all nine forage species was higher in control than treatment stands across seasons (Table 1), when arnica was excluded, combined cover of the other eight forage species or genera was roughly $20 \%$ higher in treatment than in control stands in spring $(2.84 \%$ and $2.36 \%$, respectively) and $4 \%$ lower in treatment than in control stands in summer $(2.77 \%$ and $2.88 \%$, respectively). Percentage of cover of total vegetation and shrubs was higher in control than in treatment stands $(P<0.0001)$, whereas total cover of forbs and graminoids did not differ between stand types $(P \geq 0.10)$. With respect to seasonal differences in forage abundance, cover of bluegrass, smooth brome, and arnica was higher in spring than in summer in both stand types $(P \leq 0.001)$ whereas the opposite was true for pinegrass $(P=0.0009$; Table 1$)$. In addition, cover of total vegetation and forbs was higher in spring than in summer $(P<0.0001)$, whereas total cover of graminoids and shrubs did not differ between seasons $(P \geq 0.52)$.

Forage abundance in treated stands increased slightly from 2 to $5 \mathrm{yr}$ since burning. Canonical correlation analysis, however, indicated that the only three variables contributing to overall significance (Wilk's $\Lambda=0.10, F_{48,108}=2.65, P<0.0001$ ) of the years-since-burning effect were total vegetation, total shrubs, and oatgrass. Subsequent ANOVAs indicated that the effect of years since burning on total forb cover also was nearly significant $(P=0.08)$. Percentage of cover of total vegetation and forbs also differed between seasons $(P \leq 0.03)$, so multiple comparisons for years since burning were not conducted for those variables because of insufficient error degrees of freedom. Despite the lack of formal statistical analysis, however, percentage of cover of total vegetation in treatment stands appeared to increase steadily from 3 to $5 \mathrm{yr}$ since burning in spring and from 2 to $5 \mathrm{yr}$ since burning in summer (Fig. 2). No change in total forb cover with years since burning was evident in treatment stands during spring. During summer, however, total forb cover appeared to increase substantially from 2 to $3 \mathrm{yr}$ since burning and continued to increase slowly from 3 to 5 yr since burning (Fig. 2). Total shrub cover increased steadily from 2 to 4 yr since burning and was significantly higher in 4yr-old burns than in 2-yr-old burns $(P<0.05$; Fig. 2$)$. Mean cover of oatgrass was significantly higher in 3-yr-old than in 2- 


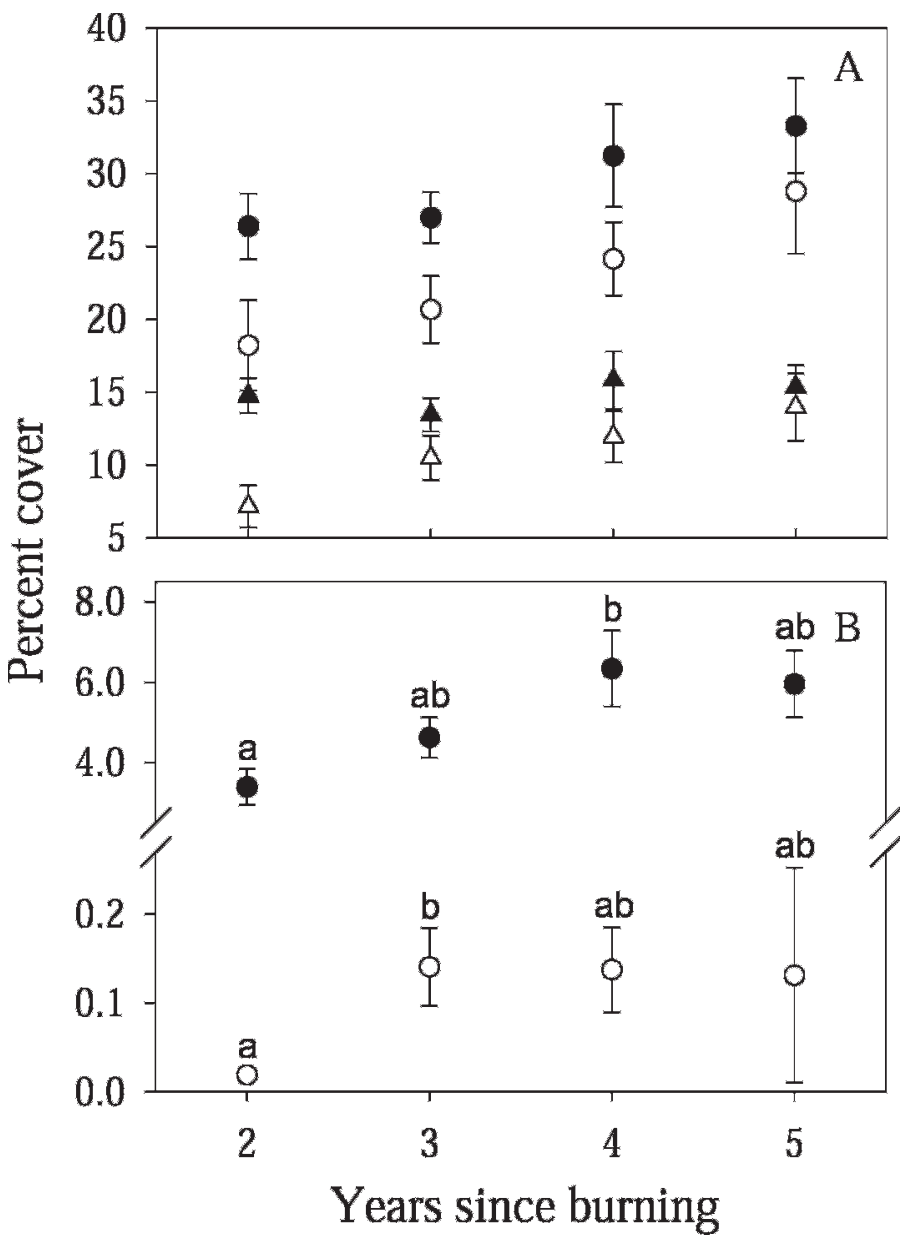

Figure 2. Percentage of cover (mean $\pm \mathrm{SE}$ ). A, Total vegetation in spring (closed circles) and summer (open circles) and total forbs in spring (closed triangles) and summer (open triangles). B, Total shrubs (closed circles) and oatgrass (Danthonia spp.; open circles) averaged across seasons in forest stands at the Starkey Experimental Forest and Range, Oregon, from 2 to $5 \mathrm{yr}$ following treatment with prescribed fire. Spring was May-June and summer was July-August. Analysis of variance indicated no significant effect of season on percentage of cover of shrubs and oatgrass ( $P \geq 0.22)$, and unshared letters among mean percentages for those variables indicate significant pairwise differences $(P<0.05)$ based on Tukey's honestly significant difference test. Multiple comparisons were not performed within seasons for total vegetation and forbs as a result of insufficient degrees of freedom (see text for details).

yr-old burns $(P<0.05)$ but did not change from 3 to 5 yr since burning (Fig. 2).

\section{Forage Quality}

Effects of fuels reduction on forage quality were similar for graminoids and forbs. In MANOVAs for both functional groups the stand type $\times$ season and year $\times$ season interactions were at least moderately significant $(P \leq 0.06)$. Further investigation revealed that differences in effects of stand type across seasons and season across years generally were in magnitude, not direction. Nevertheless, because this observation was not universal, and because all response variables contributed to significance of the interaction terms, we retained both interaction terms in all subsequent analyses to control for their effects, and we report all means and SEs by stand type, season, and year. Overall nutritional quality of graminoids in treatment and control stands at Starkey differed between stand types (Wilk's $\Lambda=0.92, \quad F_{2,149}=6.27, P=0.002$ ), seasons (Wilk's $\Lambda=0.42, \quad F_{2,149}=104.05, P<0.0001$ ), and years (Wilk's $\Lambda=0.62, F_{2,149}=46.28, P<0.0001$ ). Both digestibility and $\% \mathrm{~N}$ were higher in spring (May and June) than in summer (July and August; $P<0.0001$ ) across years and stand types and were higher in 2006 than in $2005(P=0.003$ for digestibility, $P<0.0001$ for $\% \mathrm{~N}$; Table 2). Digestibility, however, did not differ between stand types $(P=0.16)$, whereas $\% \mathrm{~N}$ was higher in control than in treatment stands $(P=0.009$; Table 2$)$. In addition, overall quality of graminoids in treatment stands was affected by years since burning (Wilk's $\left.\Lambda=0.52, F_{6,96}=6.13, P<0.0001\right)$. Digestibility did not vary with years since burning $(P=0.80)$, but $\% \mathrm{~N}$ increased from 2 to $5 \mathrm{yr}$ since burning $(P<0.0001$; Fig. 3$)$. Overall nutritional quality of forbs in treatment and control stands at Starkey differed between seasons (Wilk's $\Lambda=0.56, F_{2,128}=51.09$, $P<0.0001$ ) and years (Wilk's $\Lambda=0.96, \quad F_{2,128}=2.96$, $P=0.05$ ), but did not differ between stand types (Wilk's $\Lambda=0.98, F_{2,128}=1.15, P=0.32$ ). Both digestibility and $\% \mathrm{~N}$ were higher in spring than in summer $(P<0.0001$; Table 2$)$. Only $\% \mathrm{~N}$ differed between years $(P=0.03)$, however, and it was higher in 2006 than in 2005 across seasons and stand types (Table 2). Overall quality of forbs in treatment stands also was affected by years since burning (Wilk's $\Lambda=0.72, F_{6,86}=2.57$, $P=0.02$ ). Digestibility of forbs declined slightly from 2 to $3 \mathrm{yr}$ since burning and increased from 3 to $5 \mathrm{yr}$ since burning $(P=0.04$; Fig. 3$)$. Similarly, $\% \mathrm{~N}$ values were comparable from 2 to $3 \mathrm{yr}$ since burning and increased from 3 to $5 \mathrm{yr}$ since burning $(P=0.02$; Fig. 3$)$. Both patterns were consistent across seasons, although spring values always were higher than summer values $(P=0.0003$ for digestibility, $P<0.0001$ for $\%$ N; Fig. 3).

Effects of fuels reduction on nutritional quality of shrubs (creeping barberry only) differed slightly from effects on graminoids and forbs. Overall quality of shrubs differed between stand types (Wilk's $\Lambda=0.48, \quad F_{2,22}=11.90$, $P=0.0003$ ) and seasons (Wilk's $\Lambda=0.60, F_{2,22}=7.24$, $P=0.0038$ ), but did not differ between years (Wilk's $\left.\Lambda=0.93, F_{2,22}=0.84, P=0.45\right)$. Both digestibility and $\% \mathrm{~N}$ were higher in spring than in summer $(P=0.0008$ for digestibility, $P=0.04$ for $\% \mathrm{~N}$; Table 2 ). In contrast to graminoids and forbs, however, both measures of forage quality were higher in treatment than in control stands across years and seasons (Table 2). This effect was highly significant for digestibility $(P<0.0001)$ and nearly significant for $\% \mathrm{~N}$ $(P=0.07)$.

\section{Abiotic Ground Cover and Overstory Characterization}

The relative composition of abiotic ground cover at Starkey changed in response to fuels reduction. Abiotic cover differed between stand types (Wilk's $\Lambda=0.07, \quad F_{5,47}=130.15$, $P<0.0001$ ) and years (Wilk's $\Lambda=0.40, \quad F_{5,47}=14.26$, $P<0.0001)$, and canonical correlation analysis followed by ANOVA indicated that fuels reduction increased bare ground and reduced cover of litter and fine fuels and coarse woody 
Table 2. Percentage of in vitro dry-matter digestibility (digestibility) and percentage of nitrogen (\%N; mean \pm SE) of graminoids, forbs, and shrubs in burned (treatment) and unburned (control) forest stands during spring (May-June) and summer (July-August) at the Starkey Experimental Forest and Range (Starkey), Oregon, 2005-2006. Percentage of nitrogen can be converted to crude protein $(\mathrm{CP})$ with the equation $\mathrm{CP}=\% \mathrm{~N} \times 6.25$.

\begin{tabular}{|c|c|c|c|c|c|c|c|}
\hline \multirow[b]{2}{*}{ Plant species } & \multicolumn{2}{|c|}{ Treatment stands } & \multicolumn{2}{|c|}{ Control stands } & \multicolumn{3}{|c|}{$P$ value $^{\mathrm{a}}$} \\
\hline & Spring & Summer & Spring & Summer & Stand type & Season & Year \\
\hline \multicolumn{8}{|l|}{ Graminoids } \\
\hline Digestibility (2005) & $73.39 \pm 1.11$ & $63.20 \pm 1.21$ & $72.00 \pm 0.85$ & $64.47 \pm 0.57$ & 0.1553 & $<0.0001$ & 0.0030 \\
\hline Digestibility (2006) & $74.10 \pm 0.97$ & $67.55 \pm 0.47$ & $71.24 \pm 0.88$ & $67.39 \pm 0.60$ & & & \\
\hline$\% N(2005)$ & $1.37 \pm 0.06$ & $1.03 \pm 0.03$ & $1.43 \pm 0.05$ & $1.18 \pm 0.03$ & 0.0085 & $<0.0001$ & $<0.0001$ \\
\hline \%N (2006) & $1.66 \pm 0.05$ & $1.29 \pm 0.03$ & $1.61 \pm 0.05$ & $1.40 \pm 0.04$ & & & \\
\hline \multicolumn{8}{|l|}{ Forbs } \\
\hline Digestibility (2005) & $80.29 \pm 1.19$ & $72.77 \pm 1.45$ & $81.47 \pm 1.31$ & $74.76 \pm 1.18$ & 0.1663 & $<0.0001$ & 0.8179 \\
\hline Digestibility (2006) & $78.14 \pm 1.26$ & $75.21 \pm 1.18$ & $77.71 \pm 1.45$ & $78.58 \pm 1.29$ & & & \\
\hline$\% N(2005)$ & $2.25 \pm 0.10$ & $1.87 \pm 0.11$ & $2.34 \pm 0.10$ & $1.84 \pm 0.10$ & 0.3002 & $<0.0001$ & 0.0278 \\
\hline$\% N(2006)$ & $2.44 \pm 0.10$ & $1.87 \pm 0.08$ & $2.68 \pm 0.11$ & $1.89 \pm 0.11$ & & & \\
\hline \multicolumn{8}{|l|}{ Shrubs } \\
\hline Digestibility (2005) & $72.79 \pm 2.41$ & $71.29 \pm 2.03$ & $70.33 \pm 2.21$ & $63.54 \pm 1.57$ & $<0.0001$ & 0.0008 & 0.2375 \\
\hline Digestibility (2006) & $74.50 \pm 2.54$ & $71.68 \pm 1.38$ & $68.86 \pm 1.74$ & $65.35 \pm 1.27$ & & & \\
\hline$\% N(2005)$ & $1.72 \pm 0.09$ & $1.74 \pm 0.09$ & $1.63 \pm 0.10$ & $1.45 \pm 0.04$ & 0.0683 & 0.0422 & 0.9602 \\
\hline$\% N(2006)$ & $1.89 \pm 0.09$ & $1.58 \pm 0.05$ & $1.78 \pm 0.16$ & $1.52 \pm 0.06$ & & & \\
\hline
\end{tabular}

${ }^{a} P$ values obtained from analysis of variance.

debris $(P<0.0001 ;$ Table 3$)$. In addition, cover of litter and fine fuels was lower in 2006 than in $2005(P<0.0001)$ whereas cover of coarse woody debris and snags and stumps was higher in 2006 than in $2005(P=0.001$ for coarse woody debris, $P=0.003$ for snags and stumps; Table 3 ).

Tree densities at Starkey generally were substantially higher in control than in treatment stands across species and size classes (Fig. 4). Exceptions were densities of western larch (Larix occidentalis Nutt.) and lodgepole pine in the smallest size class (height $<135 \mathrm{~cm}$ ), which were comparable between treatment and control stands (likely as a result of regeneration), and density of ponderosa pine in the largest size class $(\mathrm{DBH} \geq 23 \mathrm{~cm})$, which was higher in treatment than in control stands (Fig. 4).

\section{DISCUSSION}

The effects of fuels reduction on quantity of forage available to elk at Starkey varied among forage species and between seasons. Although total cover of forbs, which represent the largest component of elk diets at Starkey during spring and summer (Stewart et al. 2003; Findholt et al. 2004), did not differ between treatment and control stands, cover of nine forage species or genera did change following fuels reduction. Of those nine forage species or genera, only arnica appeared to be of negligible importance to elk based on the magnitude of differences in ratios of use to availability between arnica and other species or genera (range of use/availability $=0.3-1.3$ for arnica and 2.5-1184.3 for other species or genera). This conclusion, however, is based on the assumption that availability of arnica does not vary greatly among years because fecal samples were collected prior to fuels reduction (Stewart et al. 2003). Fuels reduction increased cover of bluegrass, oatgrass, Ross' sedge, and western yarrow, and decreased cover of orchardgrass, pinegrass, smooth brome, and creeping barberry. Prior to fuels reduction, however, the former four species or genera comprised roughly $23 \%$ of undigested dry matter in elk feces whereas the latter four comprised only $11 \%$ (Stewart et al. 2003). Consequently, increased abundance of bluegrass, oatgrass, Ross' sedge, and western yarrow may represent a more biologically significant effect of fuels reduction than decreased abundance of the other four species. We note, however, that the relative importance of each of those species to elk in general varies across study sites (Kufeld 1973), and thus extrapolation of our results to other systems will require site-specific information on diet composition of elk.

Even without considering the relative contribution of different species or genera to elk diets at Starkey, overall effects of fuels reduction on percentage of cover of live (green) forage species were consistent with our hypotheses for the eight species and genera (excluding arnica) that differed significantly in cover between stand types. Combined cover of those species and genera was roughly $20 \%$ higher in treatment than in control stands in spring. In summer, however, combined cover of the same eight species and genera was slightly lower in treatment than in control stands. Although removal of forage by elk and other species in treatment stands during spring may have been partially responsible for this effect, we suggest that the most likely cause was an interaction between seasonal changes in plant phenology and substantial reduction of canopy cover in treatment stands following fuels reduction. Average summer temperatures at Starkey are considerably higher than temperatures in spring (Stewart et al. 2002). Consequently, in areas with relatively open tree canopy cover most grass species and many forbs have cured or senesced by about mid-July as a result of increased exposure to direct sunlight. Conversely, in areas with denser tree canopy cover those species often remain photosynthetically active for several weeks longer. As a result, control stands may actually provide better foraging opportunities for elk than treatment stands during hotter summer 

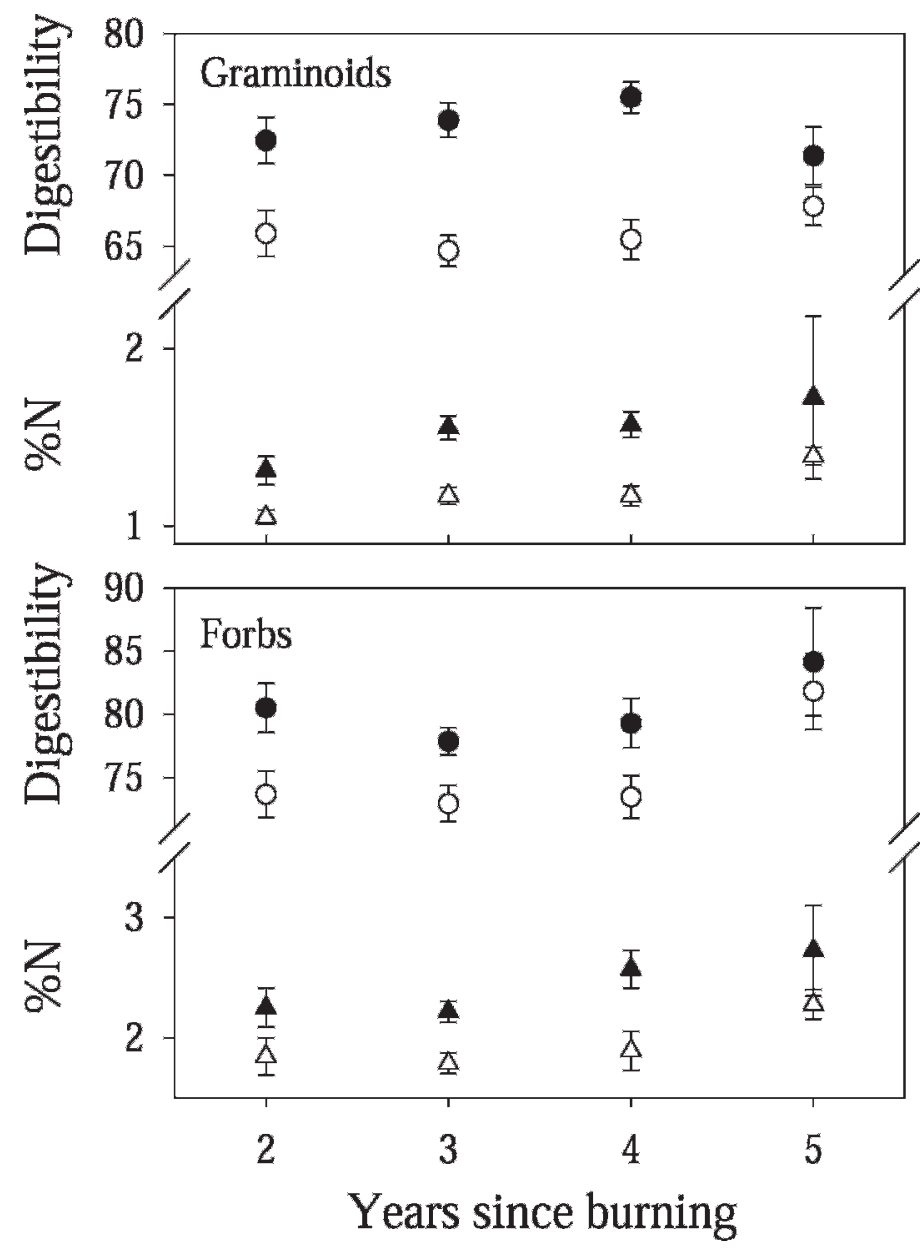

Figure 3. Percentage of in vitro dry-matter digestibility (digestibility; circles) and percentage of nitrogen (\%N; triangles) in spring (May-June; closed symbols) and summer (July-August; open symbols) for graminoids and forbs in forest stands at the Starkey Experimental Forest and Range, Oregon, from 2 to $5 \mathrm{yr}$ following treatment with prescribed fire. Data are reported as mean \pm SE.

months. This possibility is supported by results of a concurrent study, which indicated that use of control stands by elk in summer was consistently higher than use of those stands in spring, whereas the opposite was true for treatment stands (Long et al. 2008).

Cover of total vegetation and forbs, as well as oatgrass and mountain brome, also differed between years. In each case, however, cover was higher in 2006 than in 2005. This difference may have resulted from higher total precipitation between April and August at Starkey in $2006(17.0 \mathrm{~cm})$ than in $2005(14.9 \mathrm{~cm})$. Regardless, because only one of nine species that differed significantly in percentage of cover between stand types also was subject to a significant year effect, there seems little potential for annual variation in cover during the course of our study to have confounded our results regarding effects of fuels reduction on forage quantity.

Fuels reduction at Starkey affected nutritional quality of graminoids and forbs in similar ways. Contrary to our expectations, indices of nutritional quality for graminoids either did not differ between stand types (digestibility) or were higher in control than in treatment stands $(\% \mathrm{~N})$. It is interesting to note, however, that mean $\% \mathrm{~N}$ of graminoids in treatment stands increased steadily from 2 to $5 \mathrm{yr}$ following treatment, and by the fifth year after burning had exceeded maximum mean values observed in control stands in both seasons. Similarly, nutritional quality of forbs did not differ between stand types. In that case, however, both digestibility and $\% \mathrm{~N}$ increased from 2 to $5 \mathrm{yr}$ following treatment, and by the fifth year after burning mean values for both indices of forage quality had increased above maximum mean values observed in control stands in both seasons. These results indicate that nutritional quality of the nine herbaceous forage species that we sampled at Starkey may indeed have increased following application of prescribed fire, but that this response occurred more slowly than expected and was not fully apparent until at least $5 \mathrm{yr}$ postburning. Similarly, Canon et al. (1987) reported no significant effect of prescribed fire on nutritional quality of elk forage $2-3 \mathrm{yr}$ after burning. Other authors, however, have reported relatively rapid $(<1-\mathrm{yr})$ increases in nutritive value of forage species following fire (Carlson et al. 1993; Cook 2002; Schindler et al. 2004; Van Dyke and Darragh 2007). This discrepancy is difficult to explain, but may be related to adaptation of fir and pine-fir forests to frequent low-intensity fires in many areas of the Pacific Northwest (Agee 1993; Metlen et al. 2004). Such a fire regime would return relatively small quantities of nutrients to the soil on a fairly regular basis, which might at least partially dilute any selective advantage associated with rapid nutrient uptake following fire. In contrast, if influxes of soil nutrients from fire are rare, then species with the ability to rapidly sequester a large proportion of available nutrients immediately following fire would be at a significant advantage over species with slower rates of uptake.

Table 3. Percentage of cover (mean \pm SE) of four categories of abiotic ground cover in burned (treatment; $n=26$ ) and unburned (control; $n=27$ ) forest stands during 2005 and 2006 at the Starkey Experimental Forest and Range (Starkey), Oregon. Estimates are averaged across seasons. Litter and fine fuels consist of twigs, bark, leaves, needles, branches, or other organic matter lying above the mineral soil, and coarse woody debris consists of downed woody material $>10 \mathrm{~cm}$ in diameter and $>1 \mathrm{~m}$ in length.

\begin{tabular}{|c|c|c|c|c|c|c|}
\hline \multirow[b]{2}{*}{ Cover type } & \multicolumn{2}{|c|}{ Treatment stands } & \multicolumn{2}{|c|}{ Control stands } & \multicolumn{2}{|c|}{$P$ value $^{\mathrm{a}}$} \\
\hline & 2005 & 2006 & 2005 & 2006 & Stand type & Year \\
\hline Bare ground & $9.37 \pm 0.84$ & $10.39 \pm 0.77$ & $2.26 \pm 0.51$ & $2.70 \pm 0.39$ & $<0.0001$ & 0.1594 \\
\hline Litter and fine fuels & $66.02 \pm 1.48$ & $55.99 \pm 1.77$ & $79.41 \pm 1.18$ & $67.20 \pm 1.27$ & $<0.0001$ & $<0.0001$ \\
\hline Coarse woody debris & $1.79 \pm 0.31$ & $2.45 \pm 0.44$ & $9.95 \pm 0.63$ & $14.24 \pm 1.25$ & $<0.0001$ & 0.0013 \\
\hline Snags and stumps & $0.39 \pm 0.06$ & $0.70 \pm 0.11$ & $0.54 \pm 0.13$ & $1.06 \pm 0.22$ & 0.3911 & 0.0031 \\
\hline
\end{tabular}

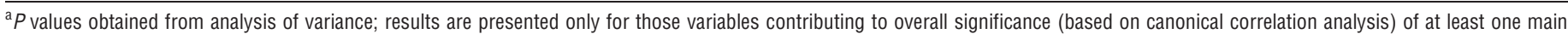
effect in a multivariate analysis of variance. 

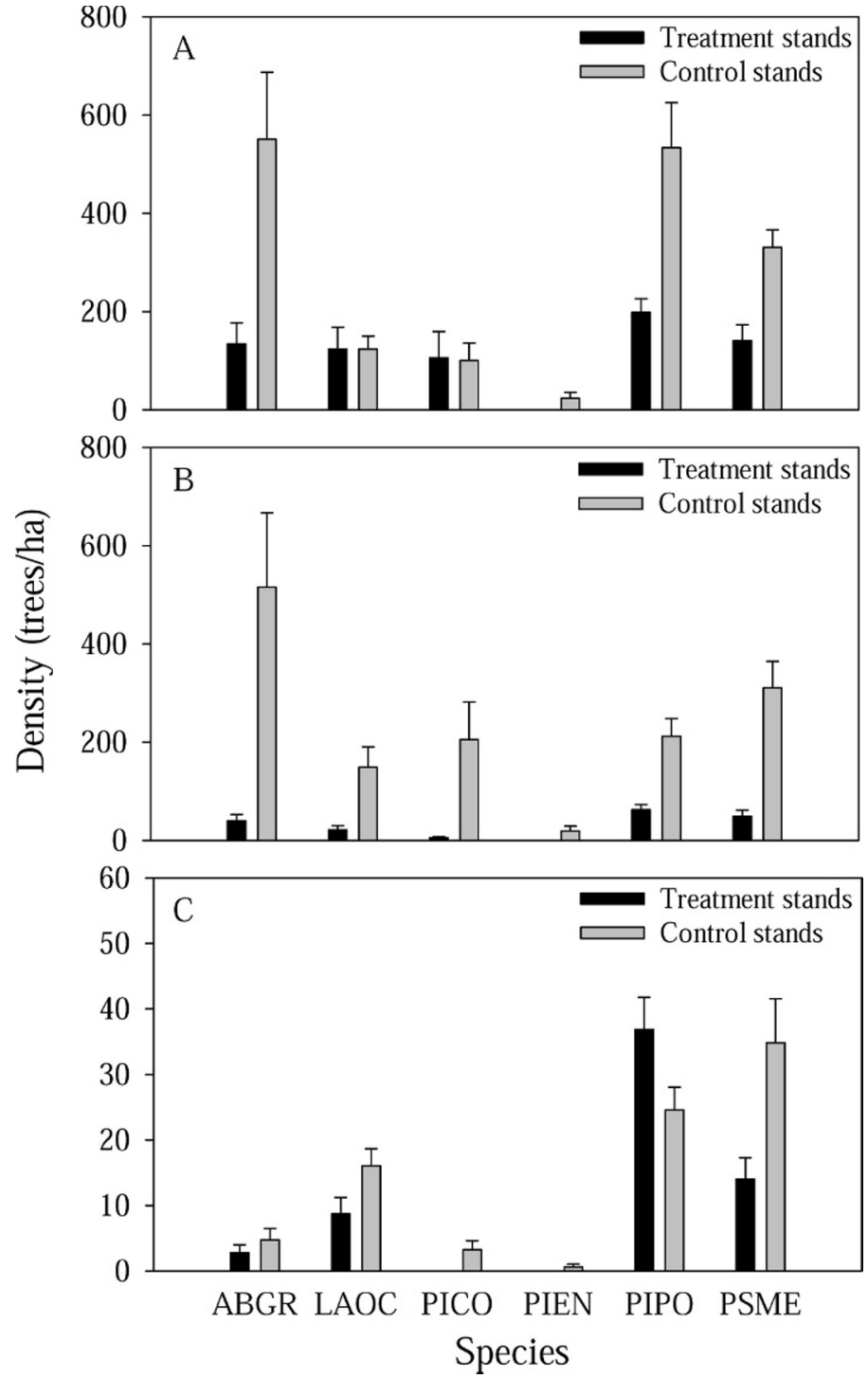

Figure 4. Density of six tree species in burned (treatment; $n=26$ ) and unburned (control; $n=27$ ) forest stands at the Starkey Experimental Forest and Range, Oregon, 2005-2006. Data are stratified by size class. A, Trees $\leq 135 \mathrm{~cm}$ tall. B, Trees $>135 \mathrm{~cm}$ tall and $<23 \mathrm{~cm}$ diameter at breast height (DBH). C, Trees $\geq 23 \mathrm{~cm}$ DBH. Species abbreviations are as follows: grand fir (Abies grandis [Dougl. ex D. Don] Lindl.; ABGR), western larch (Larix occidentalis Nutt.; LAOC), lodgepole pine (Pinus contorta Dougl. ex Loud.; PICO), Engelmann spruce (Picea engelmannii Parry ex Engelm.; PIEN), ponderosa pine (Pinus ponderosa P. \& C. Lawson; PIP0), and Douglas-fir (Pseudotsuga menziesii [Mirbel] Franco; PSME).

In contrast to graminoids and forbs, digestibility and $\% \mathrm{~N}$ of creeping barberry were higher in treatment than in control stands. Although we did not obtain shrub samples from all treatment and control stands during each sampling period in our study, consistency of the effect of fuels reduction on nutritive value of shrubs across seasons and years indicates that this effect was not strongly confounded with potential stand effects. Our results also are consistent with results of other studies in which effects of fire on nutritional quality of woody browse were evaluated. For example, Carlson et al. (1993) and Schindler et al. (2004) reported short-term increases in nutritive value (crude protein and digestibility) of woody browse following fire. Also in contrast to herbaceous species, however, shrubs historically have comprised only a small proportion of elk diets at Starkey (roughly 7\%; Stewart et al. 2003), with only one shrub species (creeping barberry) comprising $>1 \%$ of undigested dry matter in the feces. This likely is due in part to a lack of availability of woody browse, as we observed very low densities of palatable shrubs throughout Starkey during our study. As a result, it seems unlikely that the increase we documented in nutritive value of creeping barberry following fuels reduction would be of substantial benefit to elk, because fuels reduction also reduced already low abundances of that and other palatable shrubs.

Lower nutritional quality of forage in summer than in spring across plant functional groups in our study was consistent with our hypotheses, and similar patterns have been reported by other authors (Canon et al. 1987; Cook 2002; Beck and Peek 2005; Ganskopp et al. 2007). Comparable to our results for forage quantity, the decline in both digestibility and $\% \mathrm{~N}$ between spring and summer often was greater in treatment than in control stands, particularly for graminoids. This result adds further support to the hypothesis that control stands may provide higher-quality forage for elk during hotter summer months because denser tree canopy cover in those stands reduces exposure of plants to direct sunlight. Results for abiotic ground cover and tree density also reflected conversion of treatment stands to earlier successional stages (Perryman et al. 2002). We note, however, that nutritional quality of forage species sampled in our study was relatively high in both treatment and control stands across seasons, and thus forage conditions in all stands may have consistently exceeded requirements for elk (Cook et al. 2004).

\section{MANAGEMENT IMPLICATIONS}

Although prescribed fire often is assumed to benefit large herbivores by increasing quantity or quality of forage, plants with different life-history characteristics exhibit a wide range of adaptations to disturbance, and thus sites with different species assemblages and disturbance histories are not likely to respond to fuels reduction in the same way (Agee 1993). We documented moderate effects of fuels reduction from 2 to $5 \mathrm{yr}$ posttreatment on quantity and quality of forage for elk in northeastern Oregon, as well as a season effect that often differed in magnitude between stand types. As a result of the interacting effects of fuels reduction and season on forage characteristics, treated stands provided better foraging opportunities for elk during spring, whereas control stands provided better foraging opportunities during summer. These results indicate that in systems similar to Starkey, maintaining a mosaic of burned and unburned (i.e., late successional) forest habitat may provide better long-term foraging opportunities for elk than burning a large proportion of the stands on a landscape. In addition, although some of our results were consistent with those of previous studies, others were not. Such variation highlights the importance of understanding ecological consequences of fuels reduction across a wide variety of taxa and ecosystems. Management of multiple-use forest landscapes for the benefit of both humans and wildlife is a complicated 
task that is most successfully accomplished in an adaptive framework. Results of this study provide a starting point for understanding potential effects of fuels reduction on wildlife in western coniferous forests, as well as for designing future studies to increase understanding of the complex relationships between forest management and ecology.

\section{ACKNOWLEDGMENTS}

We appreciated the assistance of Starkey Project personnel, including B. Dick, R. Kennedy, and J. Nothwang. Nutritional analyses were performed by R. Kedrowski. We also thank E. Garton, P. Morgan, J. Beck, and two anonymous reviewers for helpful comments on earlier drafts of this manuscript; B. Endress and J. Beck for advice on study design and sampling methods; K. Steinhorst for statistical support; and M. Bourne, G. Tyler, M. McDaniel, J. Martin, C. McKee, and D. Reid for their hard work and assistance in the field.

\section{LITERATURE CITED}

AgEE, J. K. 1993. Fire ecology of Pacific Northwest forests. Washington, DC, USA: Island Press. $493 \mathrm{p}$.

Ayers, D. M., D. J. Bedunah, and M. G. Harrington. 1999. Antelope bitterbrush and Scouler's willow response to a shelterwood harvest and prescribed burn in western Montana. Western Journal of Applied Forestry 14:137-143.

Beck, J. L., And J. M. PeEk. 2005. Great Basin summer range forage quality: do plant nutrients meet elk requirements? Western North American Naturalist 65:516-527.

Belsky, A. J., And D. M. Blumenthal. 1997. Effects of livestock grazing on stand dynamics and soils in upland forests of the interior west. Conservation Biology 11:315-327.

BonHam, C. D. 1989. Measurements for terrestrial vegetation. New York, NY, USA John Wiley and Sons. $352 \mathrm{p}$.

Bryant, L. D., J. W. Thomas, and M. M. Rowland. 1993. Techniques to construct New Zealand elk-proof fence. Portland, OR, USA: US Department of Agriculture, Forest Service, Pacific Northwest Research Station. General Technical Report PNW-GTR-313. 17 p.

Busse, M. D., S. A. Simon, And G. M. Riegel. 2000. Tree-growth and understory response to low-severity prescribed burning in thinned ponderosa pine forests of central Oregon. Forest Science 46:258-268.

Canon, S. K., P. J. Urness, and N. V. Debyle. 1987. Habitat selection, foraging behavior, and dietary nutrition of elk in burned aspen forest. Journal of Range Management 40:433-438.

Carlson, P. C., G. W. Tanner, J. M. Wood, and S. R. Humphrey. 1993. Fire in key deer habitat improves browse, prevents succession, and preserves endemic herbs. Journal of Wildlife Management 57:914-928.

Carter, M. C., and C. D. Foster. 2004. Prescribed burning and productivity in southern pine forests: a review. Forest Ecology and Management 191:93-109.

Connelly, J. W., K. P. Reese, R. A. Fischer, and W. L. Wakkinen. 2000. Response of a sage grouse breeding population to fire in southeastern Idaho. Wildlife Society Bulletin 28:90-96.

Cook, J. G. 2002. Nutrition and food. In: D. E. Toweill and J. W. Thomas [eds.]. North American elk: ecology and management. 2nd ed. Washington, DC, USA: Smithsonian Institution Press. p. 259-349.

Cook, J. G., B. K. Johnson, R. C. Cook, R. A. Riggs, T. Delcurto, L. D. Bryant, and L. L. IRWIN. 2004. Effects of summer-autumn nutrition and parturition date on reproduction and survival of elk. Wildlife Monographs 155:1-61.

Covington, W. W., P. Z. Fulé, M. M. Moore, S. C. Hart, T. W. Kolb, J. N. Mast, S. S. Sackett, and M. R. Wagner. 1997. Restoring ecosystem health in Pinus ponderosa forests of the Southwest. Journal of Forestry 95:23-29.

Craighead, J. J., J. S. Sumner, and J. A. Mitchell. 1995. The grizzly bears of Yellowstone: their ecology in the Yellowstone ecosystem, 1959-1992. Washington, DC, USA: Island Press. 556 p.
Dodge, M. 1972. Forest fuel accumulation-a growing problem. Science 177:139-142.

Findholt, S. L., B. K. Johnson, D. Damiran, T. Delcurto, and J. G. Kie. 2004. Diet composition, dry matter intake, and diet overlap of mule deer, elk and cattle. In: J. Rahm [ED.]. Transactions of the Sixty-Ninth North American Wildlife and Natural Resources Conference; 17-21 March 2004; Spokane, WA, USA. Washington, DC, USA: Wildlife Management Institute. p. 670-686.

Ganskopp, D., L. Aguilera, and M. Vavra. 2007. Livestock forage conditioning among six northern great basin grasses. Rangeland Ecology and Management 60:71-78.

Grogan, P., T. D. Bruns, and F. S. Chapin, III. 2000. Fire effects on ecosystem nitrogen cycling in a California bishop pine forest. Oecologia 122:537-544.

Hayes, J. L., And G. E. Daterman. 2001. Bark beetles (Scolytidae) in eastern Oregon and Washington. Northwest Science 75:21-30.

Hurlbert, S. H. 1984. Pseudoreplication and the design of ecological field experiments. Ecological Monographs 54:187-211.

Johnson, R. A., AND D. W. WiChern. 2002. Applied multivariate statistical analysis. 5th ed. Upper Saddle River, NJ, USA: Prentice-Hall. 767 p.

Jourdonnais, C. S., AND D. J. Bedunah. 1990. Prescribed fire and cattle grazing on an elk winter range in Montana. Wildlife Society Bulletin 18:232-240.

KLEMmEdSON, J. 0. 1976. Effect of thinning and slash burning on nitrogen and carbon in ecosystems of young dense ponderosa pine. Forest Science 22:45-53.

KufeLd, R. C. 1973. Foods eaten by the Rocky Mountain elk. Journal of Range Management 26:106-113.

Long, R. A., J. L. Rachlow, and J. G. Kie. 2008. Response of sympatric elk and mule deer to experimental habitat manipulation: effects of season and scale. Journal of Wildlife Management (in press).

Maehr, D. S., And J. L. LaRKIN. 2004. Do prescribed fires in south Florida reduce habitat quality for native carnivores? Natural Areas Journal 24:188-197.

Mast, J. N., P. Z. Fulé, M. M. Moore, W. W. Covington, and A. E. M. Waltz. 1999. Restoration of presettlement age structure of an Arizona ponderosa pine forest. Ecological Applications 9:228-239.

Masters, R. E., R. L. Lochmiller, and D. M. Engle. 1993. Effects of timber harvest and prescribed fire on white-tailed deer forage production. Wildlife Society Bulletin 21:401-411.

McCullough, D. G., R. A. Werner, and D. Neumann. 1998. Fire and insects in northern and boreal forest ecosystems of North America. Annual Review of Entomology 43:107-127.

McCune, B., and J. B. Grace. 2002. Analysis of ecological communities. Glenden Beach, OR, USA: MjM Software Designs. 304 p.

McMahon, T. E., and D. S. deCalesta. 1990. Effects of fire on fish and wildlife. In: J. D. Walstad, S. R. Radosevich, and D. V. Sandberg [EDS.]. Natural and prescribed fire in Pacific Northwest forests. Corvallis, OR, USA: Oregon State University Press. p. 233-250.

Metlen, K. L., and C. E. Fiedler. 2006. Restoration treatment effects on the understory of ponderosa pine/Douglas-fir forests in western Montana, USA. Forest Ecology andManagement 222:355-369.

Metlen, K. L., C. E. Fiedler, and A. Youngblood. 2004. Understory response to fuel reduction treatments in the Blue Mountains of northeastern Oregon. Northwest Science 78:175-185.

Mlller, R. F., W. C. Krueger, and M. Vavra. 1981. Deer and elk use on foothill rangelands in northeastern Oregon. Journal of Range Management 34:201-204

Mitchell, J. E., P. N. S. Bartling, and R. O'Brien. 1988. Comparing cover-class macroplot data with direct estimates from small plots. American Midland Naturalist 120:70-78.

Neter, J., M. H. Kutner, C. J. Nachtsheim, and W. Wasserman. 1996. Applied linear statistical models. 4th ed. Boston, MA, USA: WCB McGraw-Hill. 1408 p.

Ottmar, R. D., and D. V. Sandberg. 2001. Wildland fire in eastern Oregon and Washington. Northwest Science 75:46-54.

Parker, G. R., and L. D. Morton. 1978. The estimation of winter forage and its use by moose on clearcuts in northcentral Newfoundland. Journal of Range Management 31:300-304.

Parsons, D. J., and S. H. Debenedetti. 1979. Impact of fire suppression on a mixedconifer forest. Forest Ecology and Management 2:21-33. 
Peck, V. R., And J. M. Peek. 1991. Elk, Cervus elaphus, habitat use related to prescribed fire, Tuchodi River, British Columbia. Canadian Field-Naturalist 105:354-362.

Pendergrass, K. L., P. M. Miller, and J. B. Kauffman. 1998. Prescribed fire and the response of woody species in Willamette Valley wetland prairies. Restoration Ecology 6:303-311.

Perryman, B. L., R. A. Olson, S. Petersburg, and T. Naumann. 2002. Vegetation response to prescribed fire in Dinosaur National Monument. Western North American Naturalist 62:414-422.

PYNE, S. J. 1997. Fire in America: a cultural history of wildland and rural fire. Seattle, WA, USA: University of Washington Press. $654 \mathrm{p}$.

Quinlan, A., M. R. T. Dale, and C. C. Gates. 2003. Effects of prescribed burning on herbaceous and woody vegetation in northern lowland meadows. Restoration Ecology 11:343-350.

Rowland, M. M., L. D. Bryant, B. K. Johnson, J. H. Noyes, M. J. Wisdom, and J. W. Thomas. 1997. The Starkey Project: history, facilities, and data collection methods for ungulate research. Portland, OR, USA: US Department of Agriculture, Forest Service, Pacific Northwest Research Station, General Technical Report PNW-GTR-296. 62 p.

Rowland, M. M., P. K. Coe, R. J. Stussy, A. A. Ager, N. J. Cimon, B. K. Johnson, and M. J. WISDom. 1998. The Starkey habitat database for ungulate research: construction, documentation, and use. Portland, OR, USA: US Department of Agriculture, Forest Service, Pacific Northwest Research Station. General Technical Report PNW-GTR-430. 48 p.

SAS InStITUTE [computer program]. 2002. SAS OnlineDoc ${ }^{\circledR}$, Version 9.1.3. Cary, NC, USA: SAS Institute, Inc.

Schindler, J. R., T. E. Fulbright, and T. D. A. Forbes. 2004. Shrub regrowth, antiherbivore defenses, and nutritional value following fire. Journal of Range Management 57:178-186.

SkovLIN, J. M. 1991. Fifty years of research progress: a historical document on the Starkey Experimental Forest and Range. Portland, OR, USA: US Department of
Agriculture, Forest Service, Pacific Northwest Research Station, General Technical Report PNW-GTR-266. 58 p.

Stewart, K. M., R. T. Bowyer, J. G. Kie, N. J. Cimon, and B. K. Johnson. 2002. Temporospatial distributions of elk, mule deer, and cattle: resource partitioning and competitive displacement. Journal of Mammalogy 83:229-244.

Stewart, K. M., R. T. Bowyer, J. G. Kie, B. L. Dick, and M. Ben-David. 2003. Niche partitioning among mule deer, elk, and cattle: do stable isotopes reflect dietary niche? Ecoscience 10:297-302.

Stewart, K. M., R. T. Bowyer, R. W. Ruess, B. L. Dick, and J. G. Kie. 2006. Herbivore optimization by North American elk: consequences for theory and management. Wildlife Monographs 167:1-24.

Tiedemann, A. R., J. O. Klemmedson, and E. L. Bull. 2000. Solution of forest health problems with prescribed fire: are forest productivity and wildlife at risk? Forest Ecology and Management 127:1-18.

Tilley, J. M. A., And R. A. Terry. 1963. A two-stage technique for the in vitro digestion of forage crops. Journal of the British Grassland Society 18:104111.

us Department of Agriculture Natural Resources Conservation Service. 2007. The PLANTS Database. Baton Rouge, LA, USA: National Plant Data Center. Available at: http://plants.usda.gov. Accessed 5 March 2007.

Van Dyke, F., and J. A. Darragh. 2007. Response of elk to changes in plant production and nutrition following prescribed burning. Journal of Wildlife Management 71:23-29.

Weekley, C. W., And E. S. Menges. 2003. Species and vegetation responses to prescribed fire in a long-unburned, endemic-rich Lake Wales Ridge scrub. Journal of the Torrey Botanical Society 130:265-282.

Wisdom, M. J., J. G. Cook, M. M. Rowland, AND J. H. Noyes. 1993. Protocols for care and handling of deer and elk at the Starkey Experimental Forest and Range. Portland, OR, USA: US Department of Agriculture, Forest Service, Pacific Northwest Research Station, General Technical Report PNW-GTR-311. 49 p. 